\title{
Iridoid Patterns of Genus Plantago L. and Their Systematic Significance
}

\author{
Rilka Taskova $^{\mathrm{a}, *}$, Ljubka Evstatieva ${ }^{\mathrm{a}}$, Nedjalka Handjieva ${ }^{\mathrm{b}}$ and Simeon Popov ${ }^{\mathrm{b}}$ \\ a Institute of Botany, Bulgarian Academy of Sciences, 1113 Sofia, Bulgaria. \\ Fax: ++3592-719-032. E-mail: rilkatas@abv.bg \\ b Institute of Organic chemistry with Centre of Phytochemistry, \\ Bulgarian Academy of Sciences, 1113 Sofia, Bulgaria \\ * Author for correspondence and reprint requests \\ Z. Naturforsch. 57c, 42-50 (2002); received August 7/October 5, 2001 \\ Plantago, Iridoid Glucosides, Chemosystematics \\ The distribution of 14 iridoid glucosides in 14 Plantago L. species (44 samples correspond- \\ ing to 18 taxa) was shown. P. tenuiflora and P. gentianoides were studied for iridoids for the \\ first time. The iridoid patterns showed a good correlation with morphological and other \\ chemical features of the representatives of genus Plantago. The studied species are grouped \\ together according to the iridoid patterns: species containing mainly aucubin (P. major, P. cor- \\ nuti, $P$. gentianoides); species containing aucubin and aucubin derivatives $(P$. subulata, \\ $P$. media); species containing aucubin and catalpol ( $P$. lanceolata, $P$. altissima, $P$. argentea, \\ P. lagopus, P. atrata); species containing aucubin and plantarenaloside ( $P$. afra, P. scabra).
}

\section{Introduction}

The genus Plantago L. comprises 265 species and has a cosmopolitan distribution (Willis, 1980). According to Pilger (1937) the genus is divided into two subgenera - Euplantago Harms (subgenus Plantago) and Psyllium (Juss) Harms. Later Rahn (1978) subdivided the genus into three subgenera: subgenus Plantago, Coronopus (Lam. et DC.) Rahn (= sect. Coronopus, subgenus Plantago sensu Pilger, 1937) and Psyllium Rahn (here are included subgenus Psyllium and 5 sections of subgenus Plantago in the sense of Pilger, 1937). Recently, Rahn (1996) proposed a new original taxonomic scheme of the genus according to which genus Plantago includes 6 subgenera: subgenus Plantago, Coronopus (Lam. et DC.) Rahn, Albicans Rahn (includes different parts of subgenus Plantago sensu Pilger, 1937), subgenus Psyllium Juss. (sensu Pilger, 1937, not in Rahn, 1978), Littorella (Bergius) Rahn (= genus Littorella Bergius) and subgenus Bougueria (Decne.) Rahn (= genus Bougueria Decne.). Some authors as Sojak (1972), Holub (1973) and Dietrich $(1980,1982)$ accept the subgenus Psyllium (Juss.) Harms as a distinct genus.

The earlier studies on genus Plantago describe the macromorphological features of the species (Decaisne, 1852; Harms and Reiche, 1895; Pilger, 1937). The later works report data of embryologi- cal characters (Misra, 1964), pollen morphology (Dietrich, 1968; Clarke and Jones, 1977; Saad, 1986), seed structure (Rezk, 1980), chromosome numbers (Dietrich, 1975, 1980; Brullo et al., 1985; Kozhuharov et al., 1974), hair types (Rahn, 1992; Andrzejewska-Golec and Swietoslawski, 1987, 1988, 1989a,b; Andrzejewska-Golec, 1992) and chemical characters. As chemotaxonomic markers have been used sugars (Gorenflot and Bourdu, 1962), phenolcarboxylic acids (AndrzejewskaGolec and Swiatec, 1986), phenylethanoid glycosides (Andary et al., 1988; Ronsted et al., 2000), flavonoid glycosides (Tomas-Barberan et al., 1988, Kawashty et al., 1994) and iridoid glucosides (Rymkiewicz, 1979; Kuzmanov et al., 1984; Andrzejewska-Golec and Swiatek, 1984; Andrzejewska-Golec et al., 1993; Andrzejewska-Golec, 1997; Ronsted et al., 2000).

Iridoid glucosides are useful chemotaxonomic markers to genus Plantago. Rymkiewicz (1979) determined that some Plantago species differ in their aucubin content. Kuzmanov et al. (1984) showed a correlation between the caryological and phytochemical data of the subgenus Plantago and subgenus Psyllium. The authors hypothesized that the separation of these subgenera had taken place in the remote past and their evolutionary development had followed different patterns. According to Andrzejewska-Golec and Swiatek (1984), Andrzejewska-Golec et al. (1993), Andrzejewska- 
Golec $(1995,1997)$ the iridoid glucosides with systematic value to genus Plantago are aucubin, catalpol, plantarenaloside, and bartsioside. Ronsted et al. (2000) confirmed that aucubin is typical for the whole genus and catalpol is characteristic only for the subgenus Albicans sensu Rahn (1996) and genus Littorella. Plantarenaloside, asperuloside and bartsioside were found in more than one subgenus.

In this paper we show the distribution of 14 iridoid glycosides in 14 Plantago species collected in Bulgaria and discuss the significance of iridoids to clarify the taxonomy and evolution of the genus Plantago.

\section{Materials and Methods}

\section{Plant material}

Samples of 44 Bulgarian natural populations of Plantago (Table 1) were collected at flowering and fruitification and the voucher specimens deposited in the herbarium of the Institute of Botany, Bulgarian Academy of Sciences (SOM). The taxa were identified according to Petrova (1995).

\section{Isolation and identification of glucosides}

P. major, $P$. cornuti: compounds $\mathbf{1 , 9}$ and $\mathbf{1 0}$ were isolated as it was described previously (Taskova et al., 1999).

P. subulata: Dried ground aerial parts (70 g) were extracted with methanol $(2 \times 0.81$ for $24 \mathrm{~h})$. The combined extracts were concentrated $(8 \mathrm{~g})$, water was added $(200 \mathrm{ml})$ and extraction with dichloroethane was performed $(3 \times 70 \mathrm{ml})$. The water phase was treated with charcoal (40 g) and elution with water (1 1), water-methanol (20:1, $\mathrm{v} / \mathrm{v} ; 1 \mathrm{l})$, water-methanol $(2: 1,1: 1, \mathrm{v} / \mathrm{v} ; 0.5 \mathrm{l})$, methanol (0.5 l), methanol-acetone (1:1, v/v; $0.51)$, and methanol-dichloroethane (1:1, v/v; $0.51)$ mixtures was carried out. The methanoldichloroethane fr $(0.6 \mathrm{~g})$ after purification on silica gel $(55 \mathrm{~g})$ yielded pure $\mathbf{1}(81 \mathrm{mg}), \mathbf{3}(17 \mathrm{mg}), \mathbf{4}$ (51 mg), 5 (9 mg), and 6 (34 mg).

P. lagopus: Dried ground aerial parts $(59 \mathrm{~g})$ were extracted with methanol $(2 \times 0.61$ for $24 \mathrm{~h})$. The combined extracts were concentrated $(5 \mathrm{~g})$, water was added $(150 \mathrm{ml})$ and extraction with dichloroethane was performed $(3 \times 50 \mathrm{ml})$. The water phase was treated with charcoal $(50 \mathrm{~g})$ and elution with water (1 1), water-methanol (20:1, v/v; 11$)$, water-methanol $(2: 1,1: 1, \mathrm{v} / \mathrm{v} ; 0.51)$, methanol (0.5 1), methanol-acetone (1:1, v/v; 0.51$)$, and methanol-dichloroethane $(1: 1, \mathrm{v} / \mathrm{v} ; 0.5 \mathrm{l})$ mixtures was carried out. The combined methanol $(0.1 \mathrm{~g})$ and methanol-acetone $(0.1 \mathrm{~g})$ frs after purification on silica gel $(22 \mathrm{~g})$ yielded pure $\mathbf{1}(15 \mathrm{mg}), \mathbf{2}$ (18 mg), 8 (17 mg), 12 (9 mg), and 13 (7 mg). The methanol-dichloroethane fr $(0.1 \mathrm{~g})$ after purification on silica gel $(11 \mathrm{~g})$ yielded pure $7(11 \mathrm{mg})$ and 8 (8 mg).

P. scabra: Dried ground aerial parts $(47 \mathrm{~g})$ were extracted with methanol $(2 \times 0.51$ for $24 \mathrm{~h})$. The combined extracts were concentrated $(5 \mathrm{~g})$, water was added $(150 \mathrm{ml})$ and extraction with dichloroethane was performed $(3 \times 50 \mathrm{ml})$. The water phase was treated with charcoal $(50 \mathrm{~g})$ and elution with water (1 1), water-methanol $(20: 1, \mathrm{v} / \mathrm{v} ; 11)$, water-methanol $(2: 1,1: 1, \mathrm{v} / \mathrm{v} ; 0.51)$, methanol (0.5 1), methanol-acetone $(1: 1, \mathrm{v} / \mathrm{v} ; 0.51)$, and methanol-dichloroethane $(1: 1, \mathrm{v} / \mathrm{v} ; 0.5 \mathrm{l})$ mixtures was carried out. The combined methanol $(0.1 \mathrm{~g})$ and methanol-acetone $(0.2 \mathrm{~g})$ frs after purification on silica gel $(35 \mathrm{~g})$ yielded pure $\mathbf{1}(13 \mathrm{mg})$ and 14 (42 mg).

The identification was achieved by ultraviolet, infrared and nuclear magnetic resonance spectroscopy (El-Naggar and Beal, 1980; Boros and Stermitz, 1990; Taskova at al., 1999).

\section{Thin layer chromatography-densitometry}

Plant extracts preparation: Dried ground aerial parts from 44 Plantago samples (1 $\mathrm{g}$ of each) were extracted with methanol $(2 \times 20 \mathrm{ml})$ for $24 \mathrm{~h}$. After the concentration of the combined extracts, water was added $(3 \mathrm{ml})$ and a threefold extraction with dichlorethane was carried out. The water layer was filtered through $3 \mathrm{~g}$ neutral alumina 90 (Merck 1077) and after concentration dissolved in $2 \mathrm{ml}$ methanol-water $(1: 1, \mathrm{v} / \mathrm{v})$.

Stock solutions and calibration: About $50 \mathrm{mg}$ of each standard (aucubin (1), catalpol (2), 10-O-acetylaucubin (3), 10-acetylmonomelittoside (5), 10cinnamoylcatalpol (7), 10-benzoylcatalpol (8), asperuloside (13), and plantarenaloside (14)) was dissolved in $2 \mathrm{ml}$ methanol. Reference solutions were prepared in the range $0.8-4 \mathrm{mg} / \mathrm{ml}$ from the stock solutions by dilution with methanol.

Thin layer chromatography: The sample solutions were applied to plates with silica gel $\mathrm{GF}_{254}$ 
Table I. Samples of Plantago studied for iridoids, collection sites and voucher numbers.

\begin{tabular}{|c|c|c|c|c|c|}
\hline Taxon & $\begin{array}{l}\text { Sample } \\
\text { No. }\end{array}$ & $\mathrm{SOM}^{\mathrm{a}}$ & Locality $^{\mathrm{b}}$, basic rock $^{\mathrm{c}}$, $\mathrm{m}$ a.s.l. ${ }^{\mathrm{d}}$ & $\begin{array}{l}\text { Pheno- } \\
\text { phase }\end{array}$ & $\begin{array}{l}\text { Collection } \\
\text { date }\end{array}$ \\
\hline P. major L. & 1 & 154168 & t. Srednogorie, Si, 1000 & $\mathrm{~F}$ & 15.06 .1996 \\
\hline \multirow[t]{2}{*}{ var. major } & 2 & 154169 & Sofia region, v. Bunovo, Si, 1000 & $\mathrm{~F}$ & 15.06.1996 \\
\hline & 3 & 154076 & Rhodopes Ms, 1. Beglika, Si, 1200 & Fr & 28.06 .1996 \\
\hline P. major L. & 4 & 154170 & Pirin M., Banderitza hut, Si, 1900 & $\mathrm{~F}$ & 07.07 .1996 \\
\hline var. intermedia & 5 & 154171 & Stara Planina M., Vezen hut, Si, 1650 & $\mathrm{~F}$ & 08.07 .1996 \\
\hline \multirow{2}{*}{ (DC.) Decne. } & 6 & 154172 & Rila M., Maljovitza hut, Si, 2100 & $\mathrm{~F}$ & 12.06 .1996 \\
\hline & 7 & 154173 & Rhodopes Ms, v. Progled, Si, 1900 & $\mathrm{Fr}$ & 18.07.1996 \\
\hline P. tenuiflora Waldst. et Kit. & 8 & 154174 & Thacian plain, v. Belozem, Ca, 100 & $\mathrm{Fr}$ & 23.08 .1996 \\
\hline P. cornuti Gouan & 9 & 151024 & Black Sea coast, t. Tzarevo, $\mathrm{Si}, 0$ & $\mathrm{~F}$ & 12.06 .1991 \\
\hline \multirow[t]{2}{*}{ P. coronopus $\mathrm{L}$. } & 10 & 154175 & Struma valley, l. Rupite, Ca, 100 & $\mathrm{~F}$ & 17.05.1997 \\
\hline & 11 & 154176 & Black Sea coast, Kiten, $\mathrm{Si}, 20$ & $\mathrm{Fr}$ & 24.06.1997 \\
\hline \multirow[t]{4}{*}{ P. subulata $\mathrm{L}$. } & 12 & 154177 & t. Srednogorie, Si, 1000 & $\mathrm{~F}$ & 15.06 .1996 \\
\hline & 13 & 154077 & Pirin M., below Vihren peak, Ca, 2300 & $\mathrm{~F}$ & 06.07 .1996 \\
\hline & 14 & 154178 & Golo Bardo M., Ca, 1000 & $\mathrm{~F}$ & 04.07 .1996 \\
\hline & 15 & 154179 & Rila M., v. Madjare, Si, 1000 & $\mathrm{~F}$ & 12.07 .1996 \\
\hline P. media $\mathrm{L}$. & 16 & 154180 & Rhodopes Ms, l. Rakovo Dere, Si, 1200 & $\mathrm{~F}$ & 27.06.1996 \\
\hline var. media & 17 & 154181 & Pirin M., 1. Pesterite, Ca, 1200 & $\mathrm{~F}$ & 0507.1996 \\
\hline P. media L. & 18 & 154182 & Ljulin M., 1. Bonsovi poljani, Si, 1000 & $\mathrm{~F}$ & 19.06.1996 \\
\hline var. urvilleana Rapin & 19 & 154183 & Vitosha M., 1. Tihia kat, Si, 1000 & $\mathrm{~F}$ & 19.06.1996 \\
\hline \multirow[t]{3}{*}{ P. atrata Hoppe } & 20 & 154184 & Vitosha M., Tserni vrah peak, Si, 2200 & $\mathrm{Fr}$ & 28.06 .1996 \\
\hline & 21 & 154185 & Pirin M., 1. Dolen Kazan, Ca, 2200 & $\mathrm{~F}$ & 07.07 .1996 \\
\hline & 22 & 154186 & Rila M., 1. Marichini Ezara, Si, 2300 & $\mathrm{Fr}$ & 28.07 .1996 \\
\hline P. gentianoides & 23 & 154187 & Slavjanka M., v. Dobrotino, Ca, 600 & $\mathrm{~F}$ & 18.05 .1996 \\
\hline Sibth. et Sm. & 24 & 154188 & Rila M., 1. Maljovitza, Si, 2100 & $\mathrm{~F}$ & 12.07 .1996 \\
\hline f. gentianoides & 25 & 154189 & Rila M., 1. Maljovitza, Si, 2000 & $\mathrm{Fr}$ & 13.07.1996 \\
\hline$P$. gentianoides & 26 & 154190 & lPirin M., Vihren hut, Si, 2000 & $\mathrm{Fr}$ & 06.07 .1996 \\
\hline f. stefanovii & 27 & 154191 & Pirin M., 1. Kabata, Ca, 2500 & $\mathrm{~F}$ & 06.07 .1996 \\
\hline (Urum. et Jav.) Hayek & 28 & 154192 & Rila M., 1. Marichini Ezara, Si, 2500 & $\mathrm{~F}$ & 28.07 .1996 \\
\hline P. lanceolata L. & 29 & 154193 & Pirin M., v. Dobriniste, Si, 600 & $\mathrm{~F}$ & 17.05 .1996 \\
\hline \multirow[t]{2}{*}{ var. lanceolata } & 30 & 154194 & Vitosha M., l. Zlatni Mostove, Si, 1400 & $\mathrm{~F}$ & 09.06 .1996 \\
\hline & 31 & 154195 & Struma valley, 1 . Rupite, $\mathrm{Ca}, 100$ & $\mathrm{~F}$ & 17.05.1997 \\
\hline P. lanceolata $\mathrm{L}$. & 32 & 154196 & Black Sea coast, t. Varna, Ca, 50 & $\mathrm{~F}$ & 24.05 .1996 \\
\hline \multirow[t]{2}{*}{ var. eriophylla Decne. } & 33 & 154197 & Vitosha M., v. Vladaja, Si, 900 & Fr & 09.06 .1996 \\
\hline & 34 & 154198 & Pirin M., 1. Pesterite, Ca, 1200 & $\mathrm{~F}$ & 05.07 .1996 \\
\hline \multirow[t]{3}{*}{ P. altissima $\mathrm{L}$. } & 35 & 154199 & t. Sofia, $\mathrm{Si}, 500$ & $\mathrm{Fr}$ & 15.06.1996 \\
\hline & 36 & 154200 & Pirin M., 1. Pesterite, Ca, 1200 & $\mathrm{Fr}$ & 05.07 .1997 \\
\hline & 37 & 154201 & Struma valley, l. Rupite, Ca, 100 & $\mathrm{~F}$ & 17.05.1997 \\
\hline P. argentea Chaix & 38 & 154202 & Golo Bardo M., Ca, 1000 & $\mathrm{Fr}$ & 10.07 .1997 \\
\hline \multirow[t]{2}{*}{ P. lagopus L. } & 39 & 154079 & Struma valley, l. Rupite, Ca, 100 & $\mathrm{~F}$ & 17.05.1997 \\
\hline & 40 & 154203 & Struma valley, l. Rupite, Ca, 100 & $\mathrm{~F}$ & 12.04 .1998 \\
\hline \multirow{3}{*}{ P. scabra Moench } & 41 & 154204 & Black Sea coast, t. Kiten, $\mathrm{Si}, 0$ & $\mathrm{Fr}$ & 24. 06.1997 \\
\hline & 42 & 154205 & Black Sea coast, Zlatni pjasatsi, $\mathrm{Si}, 0$ & $\mathrm{Fr}$ & 18.08 .1996 \\
\hline & 43 & 154080 & Black Sea coast, t. Sozopol, Si, 0 & $\mathrm{Fr}$ & 14.08.1997 \\
\hline P. afra $\mathrm{L}$. & 44 & 154206 & Mesta valley, t. Gotze Delchev, Si, 500 & $\mathrm{Fr}$ & 02.08 .1996 \\
\hline
\end{tabular}

a SOM - Herbarium of Institute of Botany, Bulgarian Academy of Sciences.

b M. - Mountain, 1. - locality, t. - town, v. - village.

c Basic rock: $\mathrm{Ca}$ - limestone, $\mathrm{Si}$ - silicate.

d $\mathrm{m}$ a.s.l. - meters above sea level.

e Phenophase: F - at flowering; Fr - at fruitification.

(Merck Cat. 5554) for compounds 3, 5, 7-8, 1314 and neutral alumina $60 \mathrm{~F}_{254}$ TypE (Merck 5550) for compounds $\mathbf{1}$ and 2. Plates were developed with mobile phases chloroform-methanol-water (60:20:4, v/v/v, lower layer) and butanol-methanol-water (70:5:10, v/v/v) respectively, and left for
1 hour at room temperature for the solvents to evaporate.

Densitometry: Scanning was performed on a Shimadzu CS-930 densitometer in a zigzag reflection mode with a slit of $0.4 \times 0.4 \mathrm{~mm}$. Compounds 3, 5, 7-8, 13-14 were determined by scanning at 
$230 \mathrm{~nm}$. Compounds $\mathbf{1}$ and $\mathbf{2}$ were scanned at $450 \mathrm{~nm}$ after charring (the plates were placed over sulfuryl chloride vapours for $60 \mathrm{~min}$ and then heated at $120^{\circ} \mathrm{C}$ for $30 \mathrm{~min}$ ).

\section{Results and Discussion}

A total of 14 compounds (Fig. 1) were isolated and identified by spectral methods and comparison with authentic reference compounds.

A thin layer chromatography-densitometry analysis was performed and the distribution of 8 iridoid glucosides $(\mathbf{1 - 3}, \mathbf{5}, \mathbf{7}, \mathbf{8}, \mathbf{1 3}$, and 14) in a total of 44 samples corresponding to 18 taxa was shown. $P$. tenuiflora and $P$. gentianoides were analyzed for iridoids for the first time. Plant samples from three localities of each taxon, when possible from habitats with different ambient conditions, were studied. The analysis showed qualitatively constant iridoid patterns of the studied species, which were not influenced by environmental conditions and phenophase.

For a better understanding of the phylogeny and the evolutionary processes in the genus the knowledge of the biosynthetic mechanisms of the iso- lated compounds was used. The probable biosynthetic routes of some of the Plantago iridoid glucosides, made in accordance with Inouye and Uesato (1986), Inouye (1991), Jensen (1991), Damtoft et al. (1993), Ronsted et al. (2000), are given by Fig. 2. In addition, the obtained data for the iridoid patterns in genus Plantago were interpreted in accordance with the known morphological, embryological, karyological and other chemical data.

Our studies were focused at higher taxonomic levels (section, subgeneric, and generic) based on a preliminary investigation, which had shown no systematic value of the iridoids at the infraspecific level. For example, the infraspecific taxa of $P$. $m a-$ jor (var. major and var. intermedia), P. media (var. media and var. urvilleana), $P$. gentianoides ( $f$. gentianoides and $f$. stefanovii), and P. lanceolata (var. lanceolata and var. eriophylla) showed no chemical differentiation concerning the iridoid pattern.

\section{P. major, P. cornuti, P. media and P. gentianoides}

A close iridoid pattern (iridoids 1, 9, 10) for $P$. major and P. cornuti was found. This was in ac-<smiles>[R20]CC1=C[C@@H](O)[C@]2([R1])C=CO[C@H](O[CH])[C@H]12</smiles>

$\begin{array}{ll}\mathbf{R}^{\mathbf{1}} & \mathbf{R}^{\mathbf{2}} \\ \mathrm{H} & \mathrm{H} \\ \mathrm{H} & \mathrm{Ac} \\ \mathrm{OH} & \mathrm{H} \\ \mathrm{OH} & \mathrm{Ac} \\ \text { OGlc } & \mathrm{H}\end{array}$

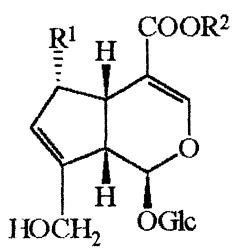

$\begin{array}{lll} & \mathbf{R}^{1} & \mathbf{R}^{2} \\ 11 & \mathrm{H} & \mathrm{H} \\ 12 & \alpha \mathrm{OH} & \mathrm{Me}\end{array}$

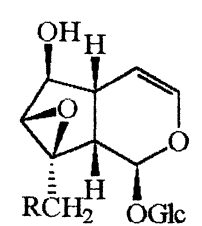

$$
\begin{aligned}
& \mathbf{R} \\
& \text { H } \\
& \text { O-cinnamoyl } \\
& \text { O-benzoyl }
\end{aligned}
$$

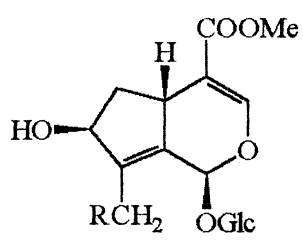

$$
\begin{array}{ll}
\mathbf{9} & \mathbf{R} \\
\mathbf{1 0} & \mathrm{OH} \\
\hline
\end{array}
$$<smiles>[CH][C@]12[C@@H](O)OC=C(C=O)[C@@]1(O)CC[C@H]2C</smiles>

14
Fig. 1. Iridoid glucosides isolated from the investigated Plantago species. 


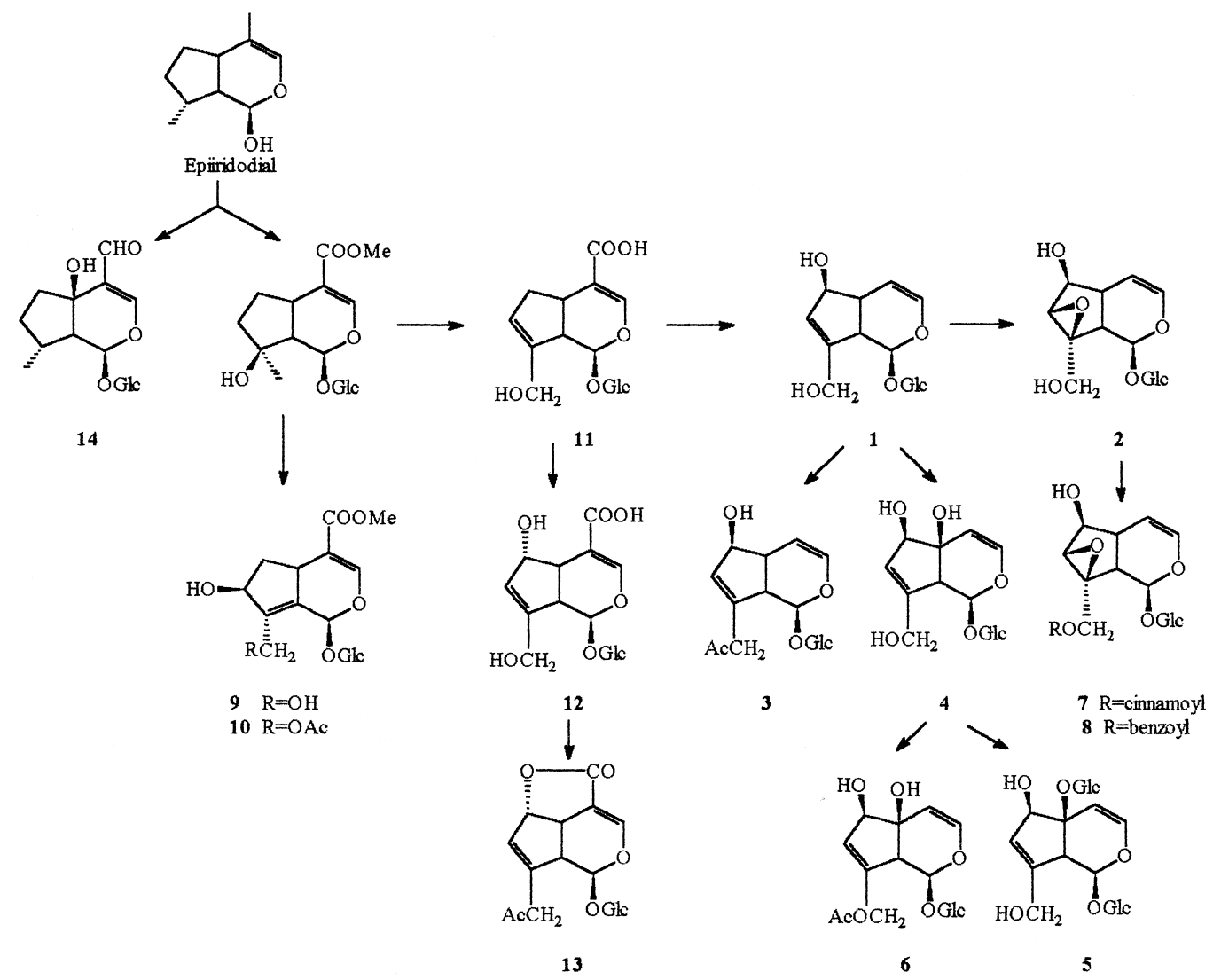

Fig. 2. Probable biosynthetic pathways to the Plantago iridoid glucosides.

cordance whit the resembling morphology and the same basic chromosome number (Table 2). Pilger includes these species into two separate sections, Polyneuron and Palaeopsyllium, which does not seem necessary. Rahn (1996) includes these two species into one section, section Plantago of subgenus Plantago. In this section the author includes also $P$. media and $P$. gentianoides which were studied here. In fact, $P$. major, $P$. cornuti and $P$. gentianoides possess similar iridoid patterns the main component was aucubin (1) accompanied with traces of other iridoids. However, the iridoid profile of $P$. media was quite different. Besides aucubin (1) $P$. media contained high concentrations of other aucubin derivatives as 10-acetylaucubin (3), monomelittoside (4), 10-O-acetoxymonomelittoside (5) and melittoside (6). This makes us suggest that probably a more correct taxonomic decision is to include $P$. media in a separate section.
The iridoid pattern of $P$. media was very similar to those of $P$. subulata (Table 2). Chilikova (1997) proved the same phenylethanoid composition of both species. Consequently, the chemical characters suggest a relation between $P$. media and P. subulata.

\section{P. coronopus and P. subulata}

We established that the distributed in Bulgaria representatives of section Coronopus (sensu Pilger, 1937) - P. coronopus and P. subulata, differed considerably in their iridoid content. $P$. coronopus contained mainly aucubin (1), while $P$. subulata beside aucubin (1) possessed 10-O-acetylaucubin (3), monomellitoside (4), 10-O-acetoxymonomelittoside (5) and melittoside (6) (Table 2). These data are in good accordance with the results of previous morphological, caryological, and phytochemical investigations: 
Table II. Occurrence of iridoid glucosides in the studied Plantago species.

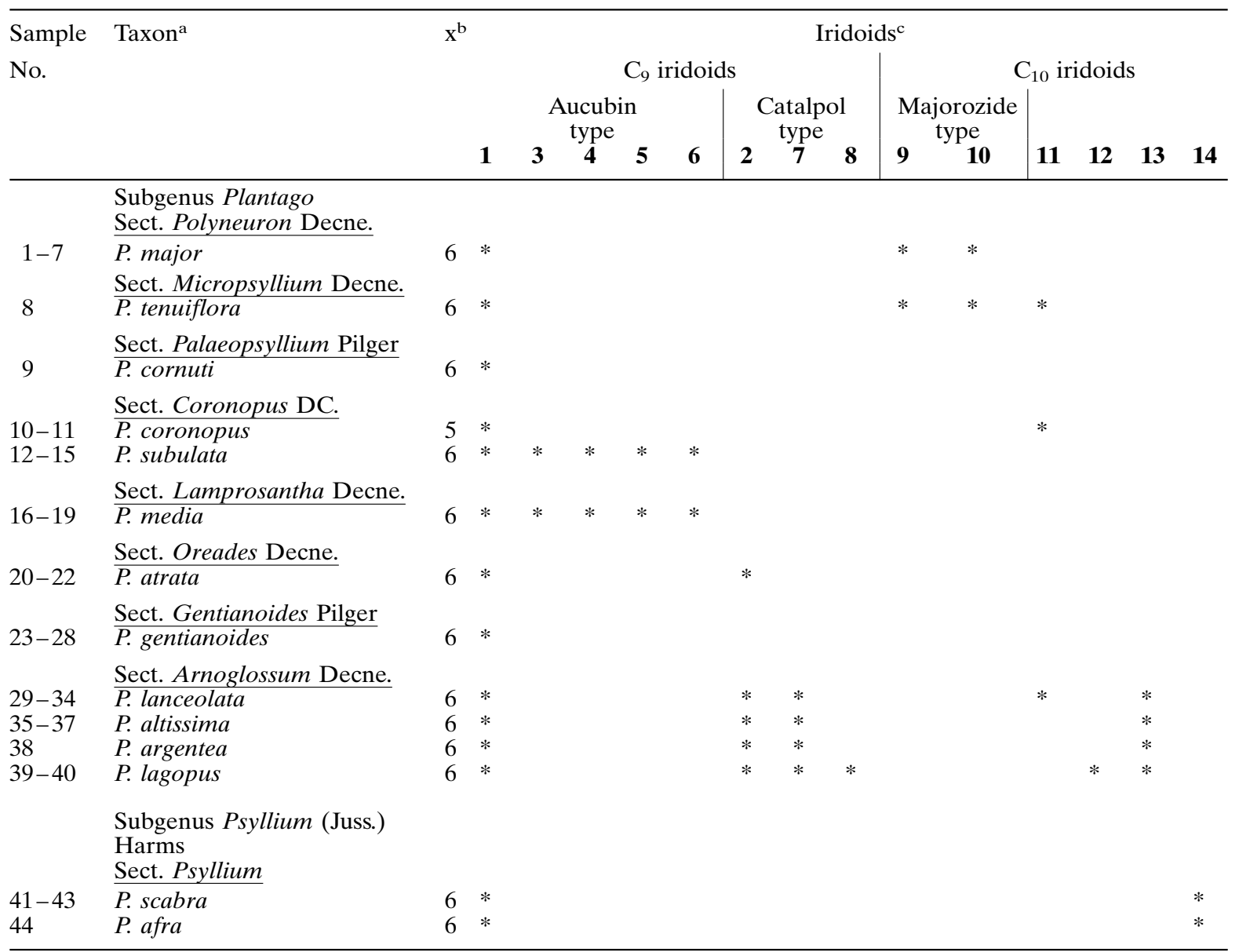

a The species are grouped in sections and subgenera according to Pilger (1937).

${ }^{\mathrm{b}}$ Basic chromosome number.

c Iridoids: aucubin (1), catalpol (2), 10-O-acetylaucubin (3), monomelittoside (4), 10-acetylmonomelittoside (5), melittoside (6), 10-cinnamoylcatalpol (7), 10-benzoylcatalpol (8), 10-hydroxymajoroside (9), 10-acetoxymajoroside (10), geniposidic acid (11), and deacetylasperulosidic acid methyl ester (12), asperuloside (13), and plantarenaloside (14).

Compounds 1-3, 5, 7, 8, 13, 14 were analyzed by thin layer chromatography-densitometry and 4, 6, 9-12 were found only in purified iridoid fractions.

Pilger (1937) divides section Coronopus into groups A and B based on morphological features. Group A includes $P$. coronopus and group B P. subulata. Gorenflot and Bourdu (1962) propose section Coronopus to be divided into two groups due to the content of ribose in the seeds and the different basic chromosome number. The P. coronopus group includes species with $\times=5$ and no ribose in the seeds, whereas the $P$. maritima goup - species with $\mathrm{x}=6$, which contain ribose in the seeds. Both groups are characterized with different pollen type (Clarke and Jones, 1977), structure of leaves and seeds (Rymkiewicz, 1979) and type of hairing (Andrzejewska-Golec and Swietoslawski, 1987). It is proved that $P$. coronopus and P. subulata differ in their iridoid (Rymkiewicz, 1979, Andrzejewska-Golec and Swiatek, 1984; Ronsted et al., 2000), flavonoid (Tomas-Barberan et al., 1988) and phenylethanoid composition (Andary et al., 1988; Ronsted et al., 2000).

Based on these data some authors changed the taxonomic scheme of Pilger (1937). Rahn (1978) 
assumes the status subgenus for section Coronopus and divides the latter into section Coronopus Lam. et DC. and section Maritima Rahn. On the other hand, Dietrich (1980) distinguishes in the frame of subgenus Plantago section Coronopus DC and section Maritima Dietrich. We think that the species $P$. coronopus and $P$. subulata must be included into two separate sections of subgenus Plantago and consequently, we support the taxonomic scheme of Dietrich (1980).

\section{P. lanceolata, $P$. altissima, $P$. argentea and P. lagopus}

These species are well distinguishable in a morphological and chemical aspect from the other representatives of genus Plantago. We established similar iridoid patterns of the four studied species. Aucubin (1), catalpol (2), catalpol esters $(\mathbf{7}, \mathbf{8})$ and $\mathrm{C}_{10}$ iridoids (11-13) were found (Table 2). These facts confirm that it is correct to combine these four species into one section - section Arnoglossum of subgenus Plantago sensu Pilger (1937) or section Lanceifolia Barneoud of subgenus Albicans sensu Rahn (1996).

In the 14 studied Plantago species, catalpol (2) was present only in the representatives of sections Arnoglossum and Oreades (P. atrata) sensu Pilger (1937). Thus, we confirm the previous results of Andrzejewska-Golec and Swiatek (1984) and Ronsted et al. (2000) for the presence of catalpol only in the representatives of sections Oreales, Arnoglossum and Bauphula Decne (the latter section has no representatives in Bulgaria) and genus Littorella. The limited occurrence of catalpol in Plantago makes this character an important taxonomic marker proving a relation among the species, which possess the ability to synthesize this compound.

Rahn (1978) includes sections Oreales, Arnoglossum and Bauphula in subgenus Psyllium Rahn. The iridoid pattern of the species studied by us was not in support of this taxonomic decision. In the representatives of subgenus Psyllium (sensu Pilger, 1937) the main iridoid was plantarenaloside (14) and they lack catalpol (2). Contrary, in species of sections Oreales, Arnoglossum and Bauphula catalpol (2) was the main iridoid. The taxonomic proposal of Rahn (1978) has been criticized by Andrzejewska-Golec and Swiatek (1984),
Andrzejewska-Golec and Swietoslawski (1988, 1989a), Andrzejewska-Golec (1992) and Andrzejewska-Golec et al. (1993) based on their chemical and micromorphological studies. Later Rahn (1996) changed his taxonomic conception and separated sections Oreales, Arnoglossum, Bauphula, Lecopsyllum and Hymenopsyllum from subgenus Psyllum including them into a new subgenus, Albicans Rahn.

\section{P. afra and $P$. scabra}

In these two species the main constituent was plantarenaloside (14) accompanied by aucubin (1) in lower concentrations (Table 2). AndrzejewskaGolec and Swiatek (1984), Andrzejewska-Golec et al. (1993) detected bartsioside in both species and considered it as an important chemosystematic marker for subgenus Psyllium. The presence of bartsioside in $P$. afra was confirmed by Ronsted et al. (2000) but this compound was also found in one representative of subgenus Plantago (Ronsted et al., 2000).

The representatives of the subgenera Plantago and Psyllium (sensu Pilger, 1937) differ in morphological (Pilger, 1937; Saad, 1986; Andrzejewska-Golec, 1992), caryological (Kuzmanov et al., 1984) and phytochemical aspect (Kuzmanov et al., 1984; Andrzejewska-Golec and Swiatek, 1984, 1986; Andrzejewska-Golec et al., 1993; Ronsted et al., 2000). This gives reason some authors (Sojak, 1972; Holub, 1973; Dietrich, 1980, 1982) to accept Psyllium as a distinct genus.

On the other hand, there is a hypothesis of a close relation between the representatives of subgenus Psyllium and the species $P$. major from subgenus Plantago. P. major is considered as an ancient species, from which have originated all other representatives of genus Plantago (Good, 1947; Croizat, 1952; Cox et al., 1977). Based on the structure and shape of the seeds Rezk (1980) considers $P$. major to stay at the base of all evolutionary lines of the seed types of genus Plantago. Saad (1986) shows that $P$. major combines features characteristic of both subgenera: it is stemless, with alternate leaves like the representatives of subgenus Plantago and simultaneously possesses pollen grains like the stemmed species of subgenus Psyllium. The author considers $P$. major as the most ancient species from which have originated and differentiated the representatives of both subgenera. 
The obtained iridoid data support this hypothesis. The main constituent in P. major is aucubin (1) and this iridoid pattern probably is the primary one. The cases, when aucubin is accompanied with other iridoids could be regarded as secondary ones.

Based on the iridoid patterns of the studied species and taking into consideration the iridoid biosynthesis (Fig. 2) we could outline several evolutionary lines in genus Plantago:

- Species, in which the iridoid biosynthesis is limited to earlier stages, containing mainly aucubin (1): $P$. major, $P$ cornuti, $P$. gentianoides.

- Species, in which aucubin (1) is a precursor of aucubin derivatives as 10-O-acetylaucubin (3), monomelittoside (4), and monomelittoside derivatives (5-6): $P$. subulata, $P$. media.

- Species, which synthesize aucubin (1) and catalpol (2): P. lanceolata, P. altissima, P. argentea,

Andary C., Motte-Florac M., Gargadennec A., Wylde R. and Heitz A. (1988), Les esters cafeiques du genere Plantago. Identification et valeur chimiotaxinomique. Plant. Med. Phytot. 22, 17-22.

Andrzejewska-Golec E. (1992), A taxonomic study of Plantago subgenus Psyllium (Miller) Harms. Bot. J. Linn. Soc. 108, 49-53.

Andrzejewska-Golec E. (1995), The occurrence of iridoids in plants. Acta Soc. Bot. Pol. 64, 181-186.

Andrzejewska-Golec E. (1997), Taxonomic aspects of the iridoid glucosides occurring in the genus Plantago L. Acta Soc. Bot. Pol. 66, 201-205.

Andrzejewska-Golec E., Ofterdinger-Daegel S., Calis I. and Swiatec L. (1993), Chemotaxonomic aspects of iridoids occurring in Plantago subg. Psyllium (Plantaginaceae). Plant Syst. Evol. 185, 85-89.

Andrzejewska-Golec E. and Swiatek L. (1984), Badania Chemotaksonomiczne rodzaju Plantago I. Analiza frakcji irydoidow. Herba Polonica 30, 9-16.

Andrzejewska-Golec E. and Swiatek L. (1986), Badania Chemotaksonomiczne rodzaju Plantago II. Analiza frakcji fenolokwasow. Herba Polonica 32, 19-31.

Andrzejewska-Golec E. and Swietoslawski J. (1987), The morphology of hairs in species of Plantago L., sectio Coronopus DC. Acta Soc. Bot. Pol. 56, 367-379.

Andrzejewska-Golec E. and Swietoslawski J. (1988), The morphology of hairs in species of Plantago L., sections Leucopsyllium Decne. and Hymenopsyllium Pilger. Acta Soc. Bot. Pol. 57, 9-19.

Andrzejewska-Golec E. and Swietoslawski J. (1989a), The morphology of hairs in species of Plantago L., sections Bauphula Decne. and Arnoglossum Decne. Acta Soc. Bot. Pol. 58, 15-45.

Andrzejewska-Golec E. and Swietoslawski J. (1989b), The morphology of hairs in species of Plantago L., sectio Oreades Decne. Acta Soc. Bot. Pol. 58, 549-561.
P. lagopus (section Arnoglossum) and P. atrata (section Oreades). The representatives of section Arnoglossum have more advanced biosynthetic pathways and contain different catalpol derivatives $(\mathbf{7}, \mathbf{8})$ and $\mathrm{C}_{10}$ iridoids (11-13).

- Species, which synthesize aucubin (1) and plantarenaloside (14): P. afra, P. scabra (subgenus Psyllium).

The obtained iridoid data for $P$. tenuiflora and $P$. coronopus were insufficient. The presence of unidentified compounds, probably with an iridoid nature, makes determination the position of $P$. tenuiflora and $P$. coronopus in the above mentioned groups impossible.

\section{Acknowledgements}

The partial support of this work by the National Foundation for Scientific Research of Bulgaria is gratefully acknowledged.

Boros C. and Stermitz F. (1990), Iridoids. An updated review. Part I. J. Nat. Prod. 53, 1055-1147

Brullo S., Pavarone P. and Terasi M. (1985), Considerazioni cariologiche sul genere Plantago in Sicilia. Candollea 40, 217-230.

Chilikova A. (1997), Diploma Thesis "Chemotaxonomic investigations on genus Plantago L.". University of Sofia, Sofia.

Clarke G. and Jones M. (1977), Plantaginaceae. In: Rev. Paleobot. Palynol. 24, The Nordwest European Polen Flora. Elsevier, Amsterdam, pp. 129-154.

Cox C., Healey I. and Moore P. (1977), Biogeography, an Ecological and Evolutionary Approach. Blackwell Scientific Publications, Oxford, London, Edinburgh and Melbourne.

Crpizat L. (1952), Mannual of Phytogeography. Junk and Co, London.

Dahlgren R. (1980), A revised system of classification of the angiosperms. Bot. J. Linn. Soc. 80, 91-124.

Damtoft S., Jensen S., Jessen C. and Knudsen T. (1993), Late stages in the biosynthesis of aucubin in Scrophularia. Phytochemistry 33, 1089-1093.

Decaisne J. (1852), Plantaginaceae. In: Prodromus systematis naturalis regni vegetabilis 13 (De Candolle A., Ed.). Paris, p. 1.

El-Naggar L. and Beal J. (1980), Iridoids. A review. J. Nat. Prod. 43, 649-707.

Dietrich H. (1968), Pollenbestimmungsschlüssel mitteleuropäischer Plantaginaceae. Math. Naturwiss R. 17, 359-361.

Dietrich H. (1975), Cytologische Untersuchungen innerhalb der Familie der Plantaginaceae II. Math. Naturwiss R. 24, 437-461.

Dietrich H. (1980), Cytologische Untersuchungen innerhalb der Familie der Plantaginaceae III. Math. Naturwiss R. 29, 559-587. 
Dietrich H. (1982), Umkombinationen in der Plantaginaceen - Gattung Psyllium Miller. Math. Naturwiss R. 31, 195-196.

Good R. (1947), The Geography of the Flowering Plants. Longmans Green \& Co, London.

Gorenflot R. and Bourdu R. (1962), Criteres biochimiques et taxonomie experimentale du genere Plantago. Rev. Cytol. Biol. Végetales 25, 349-360.

Harms H. and Reiche K. (1895), Plantaginaceae. In: Die Natürlichen Pflanzenfamilien, IV 3b (Engler A. and Prantl K., Eds.). Engelmann Publ., Leipzig.

Hegnauer R. (1969), Chemical evidence for the classification of some plant taxa. In: Perspectives in Phytochemistry (Harborne J. and Swain T., Eds.). Academic Press, London, pp. 121-138.

Holub J. (1973), New names in Phanerogamae 2. Psyllium Mill. Folia Geobot. Phytotaxonomy, Prague 8 $155-179$.

Jensen S., Nielsen B. and Dahlgren R. (1975), Iridoid compounds, their occurrence and systematic importance in the angiosperms. Botaniska Notiser 128, $148-180$.

Jensen S. (1991), Plant iridoids, their biosynthesis and distribution in angiosperms. In: Ann. Proceed. Phytochem. Soc. Europe, Ecological Chemistry and Biochemistry of Plant Terpenoids (Harborne J. and Tomas-Barberan F., Eds.). Oxford University Press, Oxford, pp. 133-158.

Inouye H. (1991), Iridoids. In: Methods in Plant Biochemistry, Vol. 7 (Harborne B., Ed.). Academic Press, London, New York, pp. 99-143.

Inouye H. and Uesato S. (1986), Biosynthesis of iridoids and secoiridoids. In: Prog. Chem. Org. Nat. Prod. (Hert W., Grisebach H., Kirby G. and Tamm C., Eds.). Springer Publ., Wien, New York, pp. 169-236.

Kawashty S., Gamal-El-Din E., Abdalla M. and Saleh N. (1994), Flavonoids of Plantago species in Egypt. Biochem. Syst. Ecol. 22, 729-733

Kozuharov S., Petrova A. and Markova T. (1974), Plantaginaceae. In: IOPB chromosome number reports XLIV (Love, A.). Taxon 23, 373-380.

Kuzmanov B., Evstatieva L., Marekov N. and Popov S. (1984), Chemosystematic study on genus Plantago L. Fitologia 24, 29-34.
Misra R. (1964), Ovule in Plantago. Curr. Scie 33, 438-439.

Petrova A. (1995), Genus Plantago L. In: Flora Rep. Bulg., Vol. X (Kozuharov St. and Kuzmanov B., Eds.). Prof. M. Drinov Publ., Sofia, pp. 334-352.

Pilger R. (1937), Plantaginaceae. In: Das Pflanzenreich (Engler A., Ed.). H. R. Engelmann Verlag, Berlin, pp. $1-466$.

Rahn K. (1978), Nomenclatorial changes within the genus Plantago L., infraspecific taxa and subdivisions of the genus. Bot. Tidsskrift 73, 106-111.

Rahn K. (1992), Trichoms within the Plantaginaceae. Nord. J. Bot. 12, 3-12.

Rahn K. (1996), A phylogenetic study of the Plantaginaceae. Bot. J. Linn. Soc. 120, 145-198.

Rezk M. (1980), Seed structure as a phylogenetic criterion. A case of Plantago seed. Egypt. J. Bot. 23, 5162.

Ronsted N., Gobel E., Franzyk H., Jensen S. and Olsen C. (2000), Chemotaxonomy of Plantago. Iridoid glucosides and caffeoyl phenylethanoid glycosides. Phytochemistry 55, 337-348.

Rymkiewicz A. (1979), Badania nad gatunkami $\mathrm{z}$ rodzaju Plantago L. z uwzglednieniem karpologii i chemotaksonomii. Monogr. Bot. 57, 71-103.

Saad S. (1986), Palynological studies in the genus Plantago (Plantaginaceae). Pollen et Spores 28, 43-60.

Sojak J. (1972), Nomenklatoticke poznamky (Phanerogamae), Casopis Narod. Muz. Odd. Prir. Praha 140, $127-134$.

Taskova R., Handjieva N., Evstatieva, L. and Popov S., (1999), Iridoid glucosides from Veronica cymbalaria, Plantago cornutii and Plantago major. Phytochemistry 52, 1443-1445.

Tomas-Barberan F., Grayer-Barkmaijer R., Gil M. and Harborne J. (1988), Distribution of 6-hydroxy-, 6-methoxy- and 8-hydroxyflavone glycosides in the Labiatae, the Scrophulariaceae and related families. Phytochemistry 27, 2631-2645.

Willis J. (1980), A Dictionary of the Flowering Plants and Ferns, 8th edn. University Press, Cambridge, UK. 